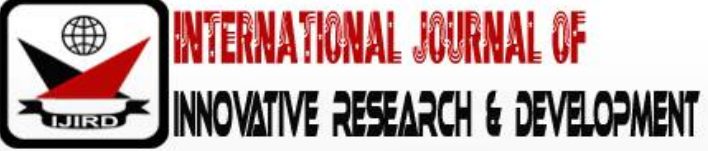

ISSN 2278 - 0211 (Online)

\section{Occupational Hazards and Safety Practices Among Welders in Port Harcourt Metropolis, Nigeria}

\author{
Nwafor, Alfred Uzoma \\ Ph.D. Student, Area of Specialization, Occupational Health and Safety Education, Nigeria \\ Irondi, Chidimma Ogbonna \\ Ph.D. Student, Area of Specialization, Occupational Health and Safety Education, Nigeria \\ Okenna, Abel Obiedelu \\ Ph.D. Student, Area of Specialization, Occupational Health and Safety Education, Nigeria
}

\begin{abstract}
:
This paper examined Occupational hazards and safety practices among welders in Port Harcourt Metropolis. The study adopted the descriptive and cross-sectional research design. The population of the study comprises about 1,127 registered members in Port Harcourt metropolis. A sample size of 315 participants was used for the study; they were selected using the simple random sampling technique. A self-structured questionnaire and interview schedule was used for data collection. The Pearson Product Moment Correlation Method (PPMC) was used to determine the reliability of the instrument and the reliability coefficient of the instrument was 0.73 was obtained. The data collected was sorted, coded and analyzed using mean scores, standard deviation, frequency tables and graphs. The results indicated that The demographics showed that majority of the welders fall between the ages of 30 years and above (50.8\%), followed by those within the age of 20-29 years (35.2\%) and those less than 20 years (14.0\%).The knowledge of welders in Port Harcourt metropolis showed chemical hazards to be $74.2 \%$, followed by physical hazards $66.0 \%$, mechanical hazard $62.7 \%$, biological hazard 33.5\%, ergonomic hazard 32.1\% and lastly psychological hazard 28.5. On Safety practices required by welders, result revealed that welders in Port Harcourt metropolis amongst others identified wearing of hand gloves to protect the hands from cuttings, use of safety goggles, based on the results it was recommended among others that there should be an occupational health service provided for welders through the informal sector segment of the National Health insurance scheme.
\end{abstract}

Keywords: Occupational hazards, safety practices, welders

\section{Introduction}

The workplace has been considered as a priority setting for the promotion of health and well-being in the $21^{\text {st }}$ century by the World Health Organization (WHO). Like other settings such as schools, hospitals, industries and cities where WHO have developed health-promoting initiatives, the workplace can have a very positive influence on the health and well-being of workers, their communities, families, and the society at large (Gebrezgiabher, Tetemke, and Yetum, 2019). Gebrezgiabher, Tetemke and Yetum (2019) posits that industrial occupations may pose unsafe work and work environment because of the built-in sources of hazard present in their process, products, material or technologies. These sources of hazards may create the risk of accidents or work-related diseases to the workers within the premises of the industry in particular and the general public that habit around the environment in general.

The International Standard Classification of Occupations (ISCO) as reported by Isah and Okojie (2006) defined welders as workers who join and cut metal parts using flame or electric arc and other sources of heat. In another definition Gebrezgiabher, Tetemke and Yetum (2019) defined welding as the process in which metal or other thermoplastic materials are joined together by the application of heat or pressure, or both with or without the use of filler metal.

Like in most developing countries such as Nigeria, Illiyasu and Lawan (2010) noted that welding is a small scale industry in Nigeria, which provides job opportunities to various people and it is not without hazards, the study noted also noted that almost every welder develops cataract, neck and back problems among other health problems. Sheikh and Bhojani (1991) discovered that the high temperature generated by the hot Oxyacetylene flame or electric current may lead to burns and electric shocks, injuries such as laceration and cuts by sharp or heated metal panes, from high velocity particles and occupational explosions of Oxyacetylene has tanks may occur.

Norn and Franck (1991); Isah and Okojie (2006) in agreement posits that the excessive lighting and exposure to ultra violet radiation may lead to "arc eye" or "flash burn" injuries to the cornea, photokeratosis and double vision which may consequently lead to the damage of the retina, hearing impairment among welders may also result from exposure to high level of noise produced by the welding and filing machines. Welders as reported by Coggen, Inskip, Winter and Pannett (1994), Illiyasu and Lawan (2019), Isah and Okojie (2006) are also exposed to noxious metal fumes which contain 
cocktail of metals such as zinc, cobalt, chromium, copper, platinum, nickel and their oxides which lead to various dysfunctions of the respiratory system and to the influenza-like condition referred to as metal fume fever. Reports have also shown carcinogenic and mutagenic effects due to chronic exposure to welding fumes in animals that may be extrapolated to man (Isah and Okojie, 2006; Haffman, Biggart and Rinchart 1998; Li and Yun 1998). Other organs, which may be affected by welding fumes according to Illiyasu and Lawan (2010), include the kidneys and the reproductive organs leading to reduction in sperm count and fecundity (the intellectual productivity of a creative imagination).

Adebiyi and Charles-Owaba (2009) opined that there will be maximum production by workers in an enduring environment that is safe and healthy. Accident does not just occur; they are caused by unsafe act and unsafe condition. The problems with unsafe condition include improper workstation design which needs to be properly addressed (Onawumi, Dunmade, Ajayi, Adebiyi and Omotosho, 2016). Nwafor and Ogulu (2018) noted that unsafe acts and unsafe conditions are Mechanical or personal hazards which exist when persons are careless and also through improperly maintained equipment or poorly designed equipment, they are seen as the most significant factor which causes an accident.

The organization of occupational health and safety services is not yet resilient enough to handle the growing demands for workers' health in the context of industrialization which includes welding workers. Hence, Illiyasu and Lawan (2010) posit that when safety practices and measures are employed among welders, the level of hazards associated with their occupation are prevented or reduced. Protective measures include use of Personal Protective Equipments (PPE) such as eye goggle, helmet, apron and fire-resistant heavy leather gloves, safety boot. Other protective measures include good house-keeping, limiting the hours of work, taking short breaks in-between world period and protective screen. From the submissions made above, it is now seen that the first step in protecting the worker is through education and training which involves the provision of information about hazards of his occupation and then controlling the hazard through engineering approach.

Health and safety related problems in developing countries have always been there and welders are among the most neglected groups of workers suffering from work-related health problems in such countries. Welding as an occupation offers employment to various individuals(mainly male youths) in Port Harcourt metropolis and they are mainly located around mechanic workshops, along major high ways and motor spare-part markets. Welders do not have any form of organised occupational health service. It is then important to employ safety practices and measures among welders which will in turn promote health and well-being of workers and also prevent or reduce the levels of health hazards that are associated with the welding occupation in Port Harcourt metropolis. Hence the aim of this study was to assess workers' level of awareness towards occupational hazards, their safety practices and the measures they adopt towards safeguarding their health and well-being at the workplace for the introduction of intervention and problemsolving modalities.

\section{Research Questions}

- What is the knowledge level of workers on occupational hazards among welders in Port Harcourt metropolis?

- What are the safety practices required by welders in Port Harcourt metropolis?

- What are the occupational health challenges among welders in Port Harcourt metropolis?

\section{Methodology}

The study was carried out in Port Harcourt Metropolis, which include the Port Harcourt City and Obio/ Akpor Local Government Areas of Rivers State. The descriptive and cross-sectional research design was adopted for the study. The population of the study included the total number of welders in the two local government areas in the metropolis, the population was derived from the association of welders in Port Harcourt metropolis with a total estimate of 1,127 members. A sample size of 315 respondents (28\% of the population), were selected for the study using the simple random sampling technique. A self-structured questionnaire and interview schedule was used for data collection. The questionnaire was validated by two experts in the Department of Human Kinetics and Health Education and an expert in measurement and evaluation, Department of Psychology, University of Port Harcourt and their corrections were effectively made and the corrected version of the questionnaire was used to collect data. The reliability of the instrument was measured using the test-retest method. 20 copies of the instrument were administered twice to 20 respondents outside Port Harcourt metropolis within two weeks and were retrieved afterwards. The Pearson Product Moment Correlation (PPMC) statistics was used to analyse the data. The reliability coefficient obtained was 0.73 which showed that the instrument was reliable. Each question was explained to the respondents to make sure they understand the issues being sought after during the interview and administration of the instrument. The data collected was sorted, coded and analysed and results were presented using mean, frequency tables and graphs. Out of the 315 instruments administered, 193 were adequately filled and used for data analysis which was about $61 \%$ return rate. 


\section{Results}

\begin{tabular}{|c|c|}
\hline Variable & Frequency (\%) \\
\hline Age & $27(14.0 \%)$ \\
\hline Less than 20 years & $68(35.2 \%)$ \\
\hline 20-29 years & $98(50.8 \%)$ \\
\hline 30 years and above & \\
\hline Work experience & $41(21.0 \%)$ \\
\hline Less than 1 year & $64(33.0 \%)$ \\
\hline 1-5 years & $88(46.0 \%)$ \\
\hline 5 years and above & \\
\hline Educational status & $17(9.0 \%)$ \\
\hline Non-formal education & $43(22.0 \%)$ \\
\hline Primary education & $102(53.0 \%)$ \\
\hline Secondary education & $31(16.0 \%)$ \\
\hline Certificate and above & \\
\hline Marital status & $118(61.1 \%)$ \\
\hline Single & $69(35.8 \%)$ \\
\hline Married & $4(2.1 \%)$ \\
\hline Widowed & $2(1.0 \%)$ \\
\hline Divorced & \\
\hline Sex & $193(100 \%)$ \\
\hline Male & Nil \\
\hline Female & Respondents
\end{tabular}

Table 1: Distribution of Socio-Demographic Data of Respondents

Table 1 shows the socio-demographic characteristics of respondents. A total of 315 respondents, with (61\%) response return rate were studied. All respondents were male. Majority of the respondents fall between the Ages of 30 and above which made up of (50.8\%) followed by age range of $20-29$ years (32.2\%) and then those less than 20 years $(14.0 \%)$. Their work experience showed that (46.0\%) were those with experience of 5 years and above followed by those with 1 to 5 years working experience which made up (35.2\%) and those less than 1-year experience (21.2\%). Educational status of the respondents showed that secondary education (53\%), primary education (22\%), certificate and above (16\%) and nonformal education (9\%). Their marital status showed that those who are single among the respondents are (61.1\%), married (35.8\%), widowed (2.1\%) and the divorced among the respondents made up (1.0\%) of the respondents.

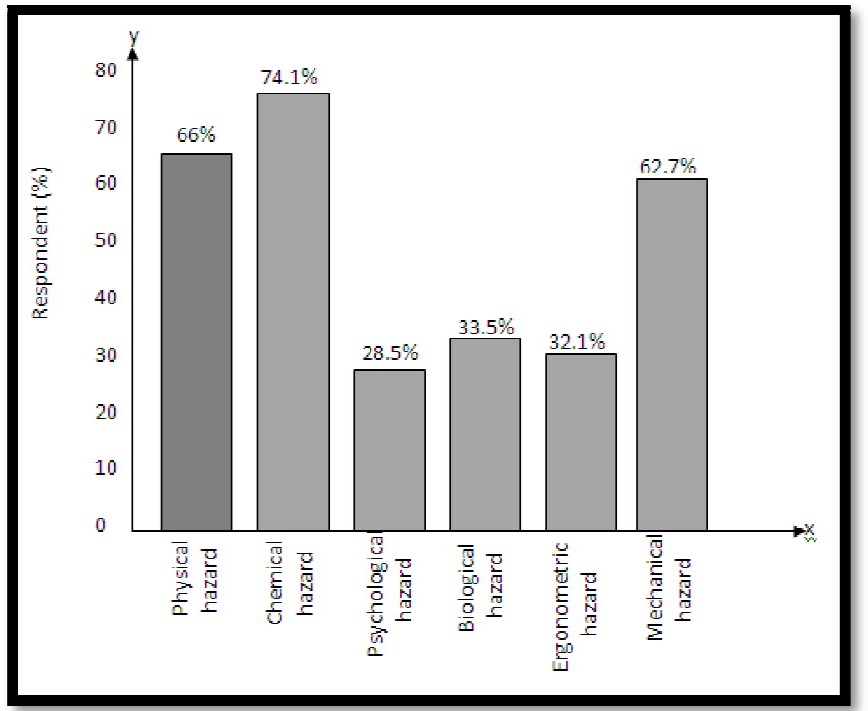

Figure 1: Knowledge Level of Workers on Occupational Hazards

Figure 1 which answered the research question one revealed the different knowledge level of respondent on occupational hazards. 127 respondents (66\%) had about physical hazards, and two-third of the respondents which is about 143 (74.1\%) knew about chemical hazards. On psychological hazard, only 55 respondents about (28.5\%) knew about it, while 74 respondents (35.5\%) knew about biological hazard. About 62(32.1\%) and 121 (62.7\%) respondents knew about ergonomic and mechanical hazards respectively. 
4.1. Research Question 2: Safety Practices among Welders in Port Harcourt Metropolis.

\begin{tabular}{|c|c|c|c|c|c|c|c|c|}
\hline S/ No. & Safety practices required & $\mathbf{N}$ & SA & $\mathbf{A}$ & D & SD & $\bar{x}$ & Decision \\
\hline 1. & $\begin{array}{l}\text { Always keep tools in good working } \\
\text { condition by cleaning, sharpening and } \\
\text { oiling after use }\end{array}$ & 193 & $\begin{array}{c}90 \\
(360)\end{array}$ & $\begin{array}{c}52 \\
(156)\end{array}$ & $\begin{array}{c}38 \\
(76)\end{array}$ & $\begin{array}{c}13 \\
(13)\end{array}$ & 3.13 & Always \\
\hline 2. & $\begin{array}{l}\text { Always wear hand gloves to protect } \\
\text { the hands from cuttings }\end{array}$ & 193 & $\begin{array}{c}53 \\
(348)\end{array}$ & $\begin{array}{c}81 \\
(243)\end{array}$ & $\begin{array}{c}43 \\
(86)\end{array}$ & $\begin{array}{c}16 \\
(16)\end{array}$ & 2.89 & Occasionally \\
\hline 3. & $\begin{array}{l}\text { I wear ear muff during machine } \\
\text { operation }\end{array}$ & 193 & $\begin{array}{c}41 \\
(164)\end{array}$ & $\begin{array}{c}58 \\
(174)\end{array}$ & $\begin{array}{c}40 \\
(80)\end{array}$ & $\begin{array}{c}53 \\
(53)\end{array}$ & 2.44 & Rarely \\
\hline 4. & Attend safety training periodically & 193 & $\begin{array}{c}11 \\
(44)\end{array}$ & $\begin{array}{c}17 \\
(51)\end{array}$ & $\begin{array}{c}73 \\
(146)\end{array}$ & $\begin{array}{c}92 \\
(92)\end{array}$ & 1.73 & Rarely \\
\hline 5. & $\begin{array}{l}\text { During machine operation, I use safety } \\
\text { goggles or face mask }\end{array}$ & 193 & $\begin{array}{c}87 \\
(348)\end{array}$ & $\begin{array}{c}79 \\
(237)\end{array}$ & $\begin{array}{c}21 \\
(42)\end{array}$ & $\begin{array}{c}6 \\
(6)\end{array}$ & 3.28 & Always \\
\hline 6. & $\begin{array}{l}\text { Ensuring that safety boots are worn } \\
\text { when working }\end{array}$ & 193 & $\begin{array}{c}49 \\
(196)\end{array}$ & $\begin{array}{c}45 \\
(135)\end{array}$ & $\begin{array}{c}63 \\
(126)\end{array}$ & $\begin{array}{c}36 \\
(36)\end{array}$ & 2.55 & Occasionally \\
\hline 7. & $\begin{array}{l}\text { Ensuring adequate hand-washing } \\
\text { always }\end{array}$ & 193 & $\begin{array}{c}31 \\
(124)\end{array}$ & $\begin{array}{c}41 \\
(123)\end{array}$ & $\begin{array}{c}72 \\
(144)\end{array}$ & $\begin{array}{c}49 \\
(49)\end{array}$ & 2.28 & Rarely \\
\hline 8. & $\begin{array}{l}\text { Ensuring adequate or proper } \\
\text { housekeeping in the workshop }\end{array}$ & 193 & $\begin{array}{c}48 \\
(192)\end{array}$ & $\begin{array}{c}42 \\
(126)\end{array}$ & $\begin{array}{c}78 \\
(156)\end{array}$ & $\begin{array}{l}25 \\
(25)\end{array}$ & 2.58 & Occasionally \\
\hline 9. & Wear apron during welding operation & 193 & $\begin{array}{c}71 \\
(284)\end{array}$ & $\begin{array}{c}49 \\
(147)\end{array}$ & $\begin{array}{c}37 \\
(74)\end{array}$ & $\begin{array}{c}36 \\
(36)\end{array}$ & 2.80 & Occasionally \\
\hline
\end{tabular}

Table 2

Table2 showed that the mean value of items 1,2, 5, 6,8 and 9 had their mean values as 3.13, 2.89, 3.28, 2.55, 2.58 and 2.80 respectively which indicated that welders in Port Harcourt metropolis adhere to the safety practices always or occasionally. The table also revealed that items 3,4 and 7 had the mean values of $2.44,1.73$ and 2.28 respectively which was below the criterion mean of 2.50. This indicates that welders in Port Harcourt metropolis rarely adhere to the safety practices in those as shown on their responses to the items.

4.2. Research question 3: Occupational Health Challenges among Welders in Port Harcourt Metropolis

\begin{tabular}{|c|c|c|}
\hline S/ No. & Occupational Health Challenges & Frequency \\
\hline 1. & Cuts & $147(76.1 \%)$ \\
\hline 2. & Catarrh & $66(34.2 \%)$ \\
\hline 3. & Bone fracture & $73(37.8 \%)$ \\
\hline 4. & Red eye / tearfulness & $138(71.5 \%)$ \\
\hline 5. & Burns & $159(82.3 \%)$ \\
\hline 6. & Foreign body in the eye & $168(87.0 \%)$ \\
\hline 7. & Electric shock & $171(88.6 \%)$ \\
\hline 8. & Back pain & $86(44.6 \%)$ \\
\hline 9. & Deafness/ loss of hearing & $29(20.2 \%)$ \\
\hline
\end{tabular}

Table 3

Table 3 revealed that out of the 193 respondents, 147(76.1\%) were aware of cuts as one or the health challenges at the workplace. The commonest health challenge in the workplace that welders were also aware of are catarrh (34.2\%), bone fracture $(37.8 \%)$, red eyes $(71.5 \%)$, burns $(82.3 \%)$ foreign body in the eye $(87.0 \%)$, electric shock $(88.6 \%)$, back pain $(44.6 \%)$ and deafness $(20.2 \%)$.

\section{Discussion of Findings}

\subsection{Socio-Demographic Analysis of the Study}

Socio-demographic characteristics of respondents in this study showed that the welding profession in Port Harcourt metropolis are all male. This is due to gender bias towards the welding occupation especially in developing country such as Nigeria. The finding also showed that majority of the welders fall between the ages of 30 years and above (50.8\%), followed by those within the age of 20-29 years (35.2\%) and those less than 20 years (14.0\%). This is in line with 
the results of similar study conducted in Benin City by Isah and Okojie (2006) and llliyasu and Lawan (2010), Onawumi et al (2016).

The educational distribution of the respondents showed that majority of the respondents had secondary education. 9\% had non-formal education, $22 \%$ primary education, $53 \%$ secondary education while those with higher certificate made up $16 \%$ of the respondents. This is a testimony of an assumption that crafts are exclusively for school drop-outs in our society. The findings here are in agreement with the findings of Onawumi et al (2016), the study conducted by Isah and Okojie (2006) and that of Isah, Okojie and Isah (2001) which revealed that there was high rate of school drop-outs among welders. Gebrezgiabher, Tetemke and Yetum (2019) in a study among welders in Ethiopia also reported that $70.4 \%$ of respondents had secondary education which agrees with this study.

The majority of welders in Port Harcourt metropolis were experienced in their occupation. Those with experience of 5 years and above made up 46\%, one to five years' experience $33.1 \%$ while those with less than one-year experience made up 21\%. This is in line with a study conducted in Kaduna by Illiyasu and Lawan (2010) which reported that majority of welders in Kano, Kaduna and Benin City received their training through hands-on apprenticeship training. More than half of the respondents in this study were single which made up $61.1 \%$ of the respondents. $35.8 \%$ are married while $1.0 \%$ was divorced. The findings are in agreement with the report of Onawumi et al (2016)that $74.2 \%$ of the respondents in their study on metal fabrication workers in Nigeria were single. The findings of this study are also in agreement with that of Gebrezgiabher, Tetemke and Yetum (2019) which showed 43.1\% of respondents with experience of above 5 years while those with 1-5 years' experience made up $42.3 \%$ respondents on the awareness of occupational hazards among welders in Aksum and Adwa towns, Ethiopia.

\subsection{Knowledge Level of Welders on Occupational Hazards}

The result of this study revealed that respondents were aware of occupational hazards in their occupation but the level of their awareness deferred in the different occupational hazards. The knowledge of welders in Port Harcourt metropolis on chemical hazards was $74.2 \%$, followed by physical hazards $66.0 \%$, mechanical hazard $62.7 \%$, biological hazard $33.5 \%$, ergonometric hazard $32.1 \%$ and lastly psychological hazard. The results of this study agree with the finding of Nyewezi and Achalu (2019) which showed that street sweepers in Port Harcourt metropolis were aware of the occupational hazards in their occupation and also identified most of the hazards. The findings as revealed also agrees with Nwafor and Ogulu (2018) who studied the occupational hazards among oil servicing company workers in Rivers State. The result shows that the workers identified chemical, physical, mechanical, biological, ergonomical, and psychological hazards as most common hazards in their workplace. The result of this study is also in line with the findings of Gebrezgiabher, Tetemke and Yetum (2019) which revealed that welders in Ethiopia (Tigray Region) had knowledge of chemical hazards, biological hazards, ergonomical hazards, mechanical hazards and psychosocial hazards.

\subsection{Safety Practices Required by Welders}

From the result of this study, it was revealed that welders in Port Harcourt metropolis identified the following as safety practices required.; keeping tools in good working condition by cleaning, sharpening and oiling after use; wearing hand gloves to protect the hands from cuttings; use of safety goggles or face mask during operations, ensuring that safety boots are worn when working, ensuring adequate or proper house-keeping in the workshop and wearing apron or coverall during welding operation, while the following were rarely required by the welders; wearing ear muff during machine operation, attending safety training periodically and ensuring adequate hand-washing always. The result of this study agrees with the study of Illiyasu and Lawan (2010), Gebrezgibher, Tetemke and Yetum (2019) Achenef (2007), Desalegn (2014) and Isah and Okojie (2006) that workers identified face mask, Helmet, Eye goggles, ear muff, apron, books, hand gloves, and hand washing as the safety practices employed during welding at their workplace.

\subsection{Occupational Health Challenges among Welders in Port Harcourt Metropolis}

The result of this study revealed that (as shown in table 3) the occupational health challenges identified by welders in Port Harcourt metropolis included cuts $76.1 \%$, catarrh $34.2 \%$, bone fracture $37.8 \%$, re eyes $71.5 \%$, burns $82.3 \%$, foreign body in the eye $87.0 \%$, electric shock $88.6 \%$, back pain $44.6 \%$ and deafness $20.2 \%$. The results in table 3 revealed that the occupational health challenges identified are in line with the study conducted by Isah and Okojie (2006) which showed that welders complaints were foreign body in the eye, cuts, burns, electric shock, back/ waist pain and eye injury. The study of this study is also in agreement with the study of Illiyasu and Lawan (2010) which showed that occupational hazards mentioned by welders in Kano city were burns, cuts, foreign body in the eyes electric shock, red eyes, back pain catarrh, deafness and bone fracture. The occupational health challenges identified in this study by the respondents could be due to the poor nature of workshop design and the absence of hydraulic lifts which are helping tools in the welding process in developed countries. Also, non-use of protective equipment, work overload and carelessness could also be factors responsible for health complaints of welders in Port Harcourt metropolis.

\section{Conclusion}

From the findings of this study, it is now obvious that there are hazards and occupational health challenges in the welding occupation. To be able to eliminate or prevent future occurrence of these hazards and improved health the welders in Rivers State should be given proper education and training on workplace hazards and the proper use of personal protective equipment. 


\section{Recommendations}

Based on the findings of this study, the researcher recommended that:

- There should be an occupational health service provided for welders through the informal sector segment of the National Health insurance scheme.

- There should be increased funding by the government on vocational and technical education for proper training of welders in Rivers State.

- The welders' in Rivers State as a matter of urgency should form a strong welders union at the state level that will represent them adequately at the appropriate tier of government.

\section{References}

i. Adebiyi, K.A. \& Charles-Owaba, O.E. (2009). Towards setting a sustainable manufacturing safety programme. Disaster Prevention and Management: An International Journal, 18(4): 388-396.

ii. Achenef, M. (2007). Assessments of knowledge and practice on safety information among factory workers in Addis Ababa. Addis Ababa University, Addis Ababa, Ethiopia.

iii. Desalegn, T. (2014). Knowledge and practices regarding safety information among textile workers in Adwa town. Science Postprint, 1(1).

iv. Gebrezgiabher, B.B., Tetemke, D. \& Ytum, T. (2009). Awareness of occupational hazards and utilization of safety measures among welders in Aksum and Adwa towns, Tigray region, Ethiopia. Journal of Environmental and Public Health, 1-7.

v. Haffman, O.T., Biggart, N.W. \& Rinchart, R.R. (1998). Evidence for the presence of mutagenic compound other than chromium in particles from mild steel welding. J. Resp. Med. 180: 55-65.

vi. Isah, E.C. \& Okojie, O.H. (2006). Occupational health problems of welders in Benin City, Nigeria. Journal of Biomedical Sciences, 5(1)L 64-69.

vii. Isah, E.C., Okojie, O.H. \& Isah, A.O. (2001). Street trading: An aspect of child labour in Benin City, Nigeria. J. Comm. Med. And Primary Health Care, 13: 48-52.

viii. Illiyasu, Z. \& Lawan, U.M. (2010). Occupational hazard perception and utilization of protective measures by welders in Kano City, Northern Nigeria. Sahel Medical Journal, 13(1): 12-19.

ix. Li, K. \& Yun, P.A. (1988). A case control study of lung cancer in Florence. J. Epid. Comm. H., 39: 244-250.

x. Norn, M. \& Franck, C. (1991). Long term changes in the outer part of the eye in welders. Prevalence of spheroid degeneration pinguecula, pterygium and cornea cicatrices. Actagohtalmol Copenh, 69(3): 382-386.

xi. Nwafor, A.U. \&Ogulu, C.B. (2018). Occupational hazards among oil and gas company workers in Nigeria. Lap LAMBERT Academic Publishing, Mauritius.

xii. Nwewezi, P.E. \& Achalu, E.I. (2019). Chemical and biological health hazards associated with street sweepers. In Port Harcourt metropolis. Trends in Educational Studies, 11(1): 172-178.

xiii. Onawumi, A.S., Ajayi, O.O., Dunmade, I.S., Adebiyi, K.A. \& Omotosho, A.O. (2016). Investigation of work-related health hazards prevalent among metal fabrication workers in Nigeria. European Journal of Engineering and Technology, 4(4): 1-10.

xiv. Sheikh, T.Q. \& Bhojani, F.A. (1991). Occupational injuries and perception of hazards among road side welding workers. Journal of Pakistan Medical Association, 41(8): 187-188. 